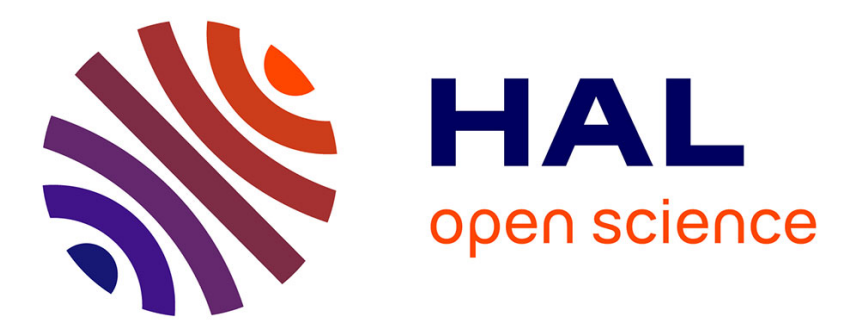

\title{
Drug survival and post-drug survival of systemic treatments in a national French cohort of children with atopic dermatitis
}

\author{
E Chambrelan, S Barbarot, L Bekel, F Poizeau, E Mahé, E Puzenat, J \\ Delaunay, S Mallet, D Bessis, A Maruani, et al.
}

\section{To cite this version:}

E Chambrelan, S Barbarot, L Bekel, F Poizeau, E Mahé, et al.. Drug survival and post-drug survival of systemic treatments in a national French cohort of children with atopic dermatitis. British Journal of Dermatology, 2020, 183 (2), pp.376-378. 10.1111/bjd.18941 . hal-02498639

\section{HAL Id: hal-02498639 \\ https://hal-univ-rennes1.archives-ouvertes.fr/hal-02498639}

Submitted on 25 Mar 2020

HAL is a multi-disciplinary open access archive for the deposit and dissemination of scientific research documents, whether they are published or not. The documents may come from teaching and research institutions in France or abroad, or from public or private research centers.
L'archive ouverte pluridisciplinaire HAL, est destinée au dépôt et à la diffusion de documents scientifiques de niveau recherche, publiés ou non, émanant des établissements d'enseignement et de recherche français ou étrangers, des laboratoires publics ou privés. 
MISS ESTEL CHAMBRELAN (Orcid ID : 0000-0002-8680-0820)

DR SEBASTIEN BARBAROT (Orcid ID : 0000-0002-6629-9100)

DR EMMANUEL MAHÉ (Orcid ID : 0000-0001-5780-1827)

PROFESSOR DIDIER BESSIS (Orcid ID : 0000-0002-3815-5417)

PROFESSOR ANNABEL MARUANI (Orcid ID : 0000-0003-3734-810X)

MRS NADIA F RAISON-PEYRON (Orcid ID : 0000-0002-7991-3165)

DR CATHERINE DROITCOURT (Orcid ID : 0000-0001-6714-6643)

Article type : Research Letter

\section{Drug survival and post-drug survival of systemic treatments in a national French cohort of children with atopic dermatitis.}

E. Chambrelan, ${ }^{1,2}$ S. Barbarot, ${ }^{3}$ L. Bekel, ${ }^{4}$ F. Poizeau,,${ }^{1,2,5}$ E. Mahé, ${ }^{6}$ E. Puzenat, ${ }^{7}$ J. Delaunay,${ }^{8}$ S. Mallet,${ }^{9}$ D. Bessis, ${ }^{10}$ A. Maruani, ${ }^{11}$ J. Miquel, ${ }^{12}$ N. Raison-Peyron,,${ }^{10}$ C. Abasq,,${ }^{13}$ A. Phan, ${ }^{14}$ A. Du Thanh, ${ }^{10}$ I. Kupfer, ${ }^{15}$ B. Bonniaud, ${ }^{16}$ G. Bouzille, ${ }^{17,18,19}$ A. Dupuy ${ }^{1,2,5}$ and C. Droitcourt, ${ }^{1,2,5}$ for the Groupe de Recherche sur l'Eczéma Atopique de la Société Française de Dermatologie (GREAT) and Société Française de Dermatologie Pédiatrique (SFDP)

\section{Affiliations:}

${ }^{1}$ Department of Dermatology, CHU Rennes, F35000 Rennes, France

${ }^{2}$ University of Rennes 1, F35000 Rennes, France

${ }^{3}$ Department of Dermatology, CHU Nantes, F44093 Nantes, France

${ }^{4}$ Department of Dermatology and Pediatric Dermatology, Necker-Enfants Malades Hospital, Assistance Publique Hôpitaux de Paris (APHP), F75015 Paris, France

${ }^{5}$ EA 7449 REPERES Pharmacoepidemiology and Health Services Research, F35000 Rennes, France

${ }^{6}$ Department of Dermatology, Hôpital Victor Dupouy, F95100 Argenteuil, France

${ }^{7}$ Department of Dermatology, CHU Besançon, F25000 Besançon, France

${ }^{8}$ Department of Dermatology, Angers University Hospital, F49933 Angers, France 
${ }^{9}$ Department of Dermatology, Timone Hospital, Assistance-publique-Hôpitaux de Marseille, F13005 Marseille, France

${ }^{10}$ Department of Dermatology, University of Montpellier, F34295 Montpellier, France

${ }^{11}$ Department of Dermatology, CHRU Tours, F37044 Tours, Centre, France

${ }^{12}$ Department of Pediatric Dermatology, Saint-Pierre University Hospital, Saint-Pierre, F97448 la Réunion, France

${ }^{13}$ Department of Dermatology, Brest University Hospital, F29200 Brest, France

${ }^{14}$ Department of Dermatology, Hôtel Dieu, Claude Bernard University, F69288 Lyon cedex 02, France

${ }^{15}$ Department of Dermatology, CH Niort, F79000 Niort, France

${ }^{16}$ Department of Dermatology, Dijon University Hospital, F21000 Dijon, France

${ }^{17}$ INSERM U1099, Rennes, France

${ }^{18}$ Clinical Data Center CHU Rennes, Rennes, France

${ }^{19}$ INSERM CIC 1414, Rennes, France

Corresponding author: Dr DROITCOURT Catherine

Mailto: catherine.droitcourt@chu-rennes.fr

Type of article: Research letter

Key words: atopic dermatitis, children, immunosuppressive treatment, drug survival, post-drug survival

Words: 800; Table: 1.

\section{Statements:}

Funding statement: this research received no specific grant from any funding agency in the public, commercial or notfor-profit sectors.

Competing Interests statement: E. Mahé declares having competing interests with Novartis and Sanofi. 


\section{Dear Editor,}

Systemic immunosuppressive treatments (IS) are restricted to severe atopic dermatitis (AD) in children. We described the IS use (first and second-line) for children with AD in a French retrospective national cohort, by using two survival analyses: 'drug survival' (DS, defined as the duration of treatment) and 'post-drug survival' (PDS, defined as the time between the end of first-line and the beginning of second-line).

Children with AD aged 0 to 18 years, started with at least one IS from 2008 to 2018 and seen by members of French research groups (15 specialized centres), were included in the DS analysis. Discontinuation of IS was the event of interest in DS analysis; observations were censored if patients were lost to follow-up or still under treatment at the end of the study. Children who discontinued their first-line IS were included in the PDS analysis. The event was the start of a second-line IS; data were censored in case of loss-to-follow-up or absence of event after a 24-month period. DS and PDS were analysed with Cox regression models in patients on ciclosporin (CIC) and methotrexate (MTX), because of the small numbers of patients treated with other IS.

Eighty-three children (mean age $11 \pm 8.7$ years, $53 \%$ boys, $75 \%$ with age of $\mathrm{AD}$ onset before 2) were included. Among them, 65\% had asthma, 49\% allergic rhinitis and $42 \%$ allergic conjunctivitis. Previous treatments included topical corticosteroids (100\%), topical calcineurin inhibitors (67\%), and phototherapy (11\%). The first-line IS was CIC for 60 patients (mean starting dose $3.2 \pm 5.6 \mathrm{mg} / \mathrm{kg}$ ); MTX for 18 (mean starting dose $0.2 \pm 0.2 \mathrm{mg} / \mathrm{kg} / \mathrm{week}$ ); acitretin for 3, dupilumab (DUPI) and omalizumab for 1 patient. The reasons for discontinuation $(\mathrm{n}=60)$ were: failure for $17(36 \%)$ children under CIC and $8(80 \%)$ with MTX; controlled AD for 18 (38\%) patients under CIC and 2 (20\%) with MTX; adverse events for 11 (18\%) children under CIC and no patient with MTX. Although the distribution of the 3 reasons for discontinuation was not globally statistically significant ( $\mathrm{p}=0.88$ ), CIC and MTX tend to have distinct profiles.

The median DS for first-line was 11.5 (IQR: 6.3-20.7) and 22.3 (IQR: 5.8-38.2) months for CIC and MTX respectively $(\mathrm{p}=0.01)$. The only predictive factor for longer DS was the MTX use (Table 1). A second-line IS was prescribed to 39 patients: CIC for 10 (25.6\%), MTX and DUPI for 13 each (33.3\%), mycophenolate mofetil, azathioprine and acitretin for one patient.

The median PDS was 8.0 and 4.1 months for CIC and MTX respectively ( $\mathrm{p}=0.58)$. Age at AD onset under 2, respiratory allergy and controlled $\mathrm{AD}$ at the end of first-line were predictive factors of longer PDS. The predictive factors for shorter PDS were high-dose of first-line treatment and male gender (Table1).

The median DS for the second-line IS was 31.5 (IQR:8.5-78.3) and 13.5 (IQR:5.5-50.1) months for CIC and MTX respectively $(\mathrm{p}=0.88)$. No determinant of DS for second-line was found.

This first comparative study of the different first and second-line IS among AD children, in a dailypractice cohort, shows different treatment profiles: time under treatment was longer for MTX than for CIC but second-line IS seemed to be required sooner.

A few studies focused on ' $\mathrm{DS}$ in $\mathrm{AD}^{1-6}$ (only 2 included children ${ }^{5,6}$ ). The median $\mathrm{DS}$ of 12 months for $\mathrm{CIC}$ as first-line is slightly longer than in previous studies ${ }^{1,5,6}$. However, they were conducted in adults or in both 
adults and children. Our findings could be explained by a better safety profile in paediatric populations. A similar median DS for MTX (22 months) was reported in two studies ${ }^{4,6}$, while one study reported only half that duration $^{2}$. These results potentially illustrate a tendency to consider that the MTX safety profile is identical for adults and children. However, 'DS' analysis is difficult to interpret, depending on the physicians and patients' behaviour, drugs available ${ }^{7}$, expert recommendations, etc.. This context is likely to vary significantly, so a comparison is difficult to make in the different contexts. For AD, the advent of DUPI for adults has already changed practices; here, it is the second most prescribed second-line IS (equal to MTX).

'PDS' analysis ${ }^{6}$ provides information about both the benefit of first-line and of treatment-free period. The only result available for PDS showed a median shorter time for CIC (2 months) than for MTX (12 months $)^{6}$. Contrasting with these results, we found a tendency for longer median PDS with CIC (8 months) vs MTX (4 months). The large proportion of patients who discontinued the MTX because of failure could explain the shorter PDS. However, treatment discontinuation could also be decided on a combination of arguments (efficacy or failure, adverse events, patient compliance).

To conclude, in addition to clinical trials, DS and PDS analyses give comprehensive information on the IS use for children with AD. Further studies should be performed with drugs that are becoming available, DUPI in particular. 


\section{REFERENCES}

1. Van der Schaft J, Politiek K, van den Reek JMPA, et al. Drug survival for ciclosporin A in a long-term daily practice cohort of adult patients with atopic dermatitis. Br J Dermatol. 2015 Jun;172(6):1621-7.

2. Politiek K, van der Schaft J, Coenraads PJ, et al. Drug survival for methotrexate in a daily practice cohort of adult patients with severe atopic dermatitis. Br J Dermatol. 2016 Jan;174(1):201-3.

3. Van der Schaft J, Politiek K, van den Reek JMPA, et al. Drug survival for azathioprine and entericcoated mycophenolate sodium in a long-term daily practice cohort of adult patients with atopic dermatitis. Br J Dermatol. 2016 Jul;175(1):199-202.

4. Gerbens LAA, Hamann SAS, Brouwer MWD, et al. Methotrexate and azathioprine for severe atopic dermatitis: a 5-year follow-up study of a randomized controlled trial. Br J Dermatol. 2018 Jun;178(6):1288-96.

5. Daguzé J, Aubert H, Bernier C, et al. A Monocentric Retrospective Cohort of Patients with Severe Atopic Dermatitis Treated with Cyclosporine A in Daily Practice. Acta Derm Venereol. 2017;97(8):955-6.

6. Law Ping Man S, Bouzillé G, Beneton N, et al. Drug survival and postdrug survival of first-line immunosuppressive treatments for atopic dermatitis: comparison between methotrexate and cyclosporine. J Eur Acad Dermatol Venereol. 2018 Aug;32(8):1327-35.

7. Van den Reek JMPA, Kievit W, Gniadecki R, et al. Drug Survival Studies in Dermatology:Principles, Purposes, and Pitfalls. J Invest Dermatol. 2015 Jul;135(7):1-5. 
Table 1. Determinants of 'drug survival' (first and second-line) and 'post-drug survival' after first-line immunosuppressive treatments, using univariate and multivariate Cox regression analyses.

\begin{tabular}{|c|c|c|c|c|c|c|}
\hline \multirow[b]{2}{*}{ Variable } & \multicolumn{3}{|c|}{ Univariate model } & \multicolumn{3}{|c|}{ Multivariate model } \\
\hline & HR & $95 \% \mathrm{CI}$ & $p$ & HR & $95 \% \mathrm{CI}$ & $p$ \\
\hline \multicolumn{7}{|l|}{ Drug survival (first-line) } \\
\hline Age* & 0.97 & $0.90-1.05$ & 0.48 & 1.02 & $0.95-1.10$ & 0.52 \\
\hline Gender (ref: female) & 0.70 & $0.41-1.19$ & 0.2 & 0.62 & $0.35-1.11$ & 0.11 \\
\hline $\begin{array}{l}\text { Age of onset of } \mathrm{AD}<2 \text { years (ref }>2 \\
\text { years) }\end{array}$ & 1.22 & $0.55-2.72$ & 0.62 & - & - & - \\
\hline Rhinitis $^{\dagger}$ & 0.61 & $0.36-1.02$ & 0.06 & 0.71 & $0.39-1.27$ & 0.25 \\
\hline Conjunctivitis ${ }^{\dagger}$ & 0.60 & $0.36-1.02$ & 0.06 & 0.79 & $0.43-1.46$ & 0.47 \\
\hline Food allergy ${ }^{\dagger}$ & 0.99 & $0.59-1.65$ & 0.96 & - & - & - \\
\hline Respiratory allergy ${ }^{\dagger}$ & 0.78 & $0.45-1.34$ & 0.37 & - & - & - \\
\hline Overweight*情 & 1.42 & $0.63-3.20$ & 0.39 & - & - & - \\
\hline Treatment for asthma ${ }^{* \dagger}$ & 0.72 & $0.43-1.21$ & 0.21 & 0.86 & $0.48-1.54$ & 0.63 \\
\hline MTX (ref CIC) & 0.40 & $0.19-0.83$ & 0.01 & 0.37 & $0.17-0.80$ & 0.01 \\
\hline \multicolumn{7}{|l|}{ Post-drug survival } \\
\hline Age* & 1.08 & $0.98-1.18$ & 0.11 & 1.07 & $0.95-1.19$ & 0.23 \\
\hline Gender (ref: female) & 2.42 & $1.18-4.89$ & 0.15 & 2.48 & $1.06-5.80$ & 0.03 \\
\hline $\begin{array}{l}\text { Age at onset of } \mathrm{AD}<2 \text { years }(\mathrm{ref}>2 \\
\text { years) }\end{array}$ & 0.51 & $0.20-1.35$ & 0.18 & 0.23 & $0.07-0.76$ & 0.01 \\
\hline Asthma $^{\dagger}$ & 0.67 & $0.34-1.31$ & 0.24 & - & - & - \\
\hline Rhinitis ${ }^{\dagger}$ & 0.96 & $0.48-1.89$ & 0.90 & - & - & - \\
\hline Conjunctivitis ${ }^{\dagger}$ & 1.23 & $0.62-2.43$ & 0.55 & - & - & - \\
\hline Food allergy ${ }^{\dagger}$ & 0.57 & $0.29-1.12$ & 0.10 & 0.42 & $0.18-1.01$ & 0.05 \\
\hline Respiratory allergy ${ }^{\dagger}$ & 0.49 & $0.25-0.95$ & 0.04 & 0.22 & $0.08-0.54$ & $<0.01$ \\
\hline Overweight* ${ }^{*} \neq$ & 1.11 & $0.38-3.19$ & 0.84 & - & - & - \\
\hline MTX (ref: CIC) & 1.38 & $0.62-3.06$ & 0.43 & 2.01 & $0.67-6.03$ & 0.20 \\
\hline High dose of treatment ${ }^{* * *}$ & 1.62 & $0.81-3.21$ & 0.17 & 2.87 & $1.09-7.57$ & 0.03 \\
\hline $\begin{array}{l}\text { Long duration of first-line } \\
\text { treatment }{ }^{\dagger \S}\end{array}$ & 1.00 & $0.50-2.01$ & 1.00 & 2.58 & $0.94-7.09$ & 0.06 \\
\hline Controlled $\mathrm{AD}^{\dagger \uparrow}$ & 0.47 & $0.23-0.96$ & 0.04 & 0.24 & $0.08-0.66$ & $<0.01$ \\
\hline
\end{tabular}

All data were collected from medical records using a standardized questionnaire

* At the initiation of first-line immunosuppressive treatment. 


\section{$\dagger$ Reference: none.}

$\$$ Defined as a Body Mass Index greater than the 97 th percentile for the correlated age and gender category.

${ }^{* *}$ Defined as $>0.3 \mathrm{mg} / \mathrm{kg} /$ week for MTX; $>3.5 \mathrm{mg} / \mathrm{kg} /$ day for CIC.

$\S$ Defined as a duration of treatment $>12$ months for MTX and $>6$ months for CIC.

"At the end of first-line immunosuppressive treatment. 